San Jose State University

SJSU ScholarWorks

Mineta Transportation Institute Publications

$1-2021$

\title{
Numerical Investigations of Transient Wind Shear from Passing Vehicles Near a Road Structure (Part I: Unsteady Reynolds- Averaged Navier-Stokes Simulations)
}

\author{
Hamid Rahai \\ California State University, Long Beach \\ Assma Begum \\ California State University, Long Beach
}

Follow this and additional works at: https://scholarworks.sjsu.edu/mti_publications

Part of the Aerodynamics and Fluid Mechanics Commons, and the Transportation Commons

\begin{abstract}
Recommended Citation
Hamid Rahai and Assma Begum. "Numerical Investigations of Transient Wind Shear from Passing Vehicles Near a Road Structure (Part I: Unsteady Reynolds-Averaged Navier-Stokes Simulations)" Mineta Transportation Institute Publications (2021). https://doi.org/10.31979/mti.2020.1933
\end{abstract}

This Report is brought to you for free and open access by SJSU ScholarWorks. It has been accepted for inclusion in Mineta Transportation Institute Publications by an authorized administrator of SJSU ScholarWorks. For more information, please contact scholarworks@sjsu.edu. 


\section{SJSU SAN UOSE STATIE}

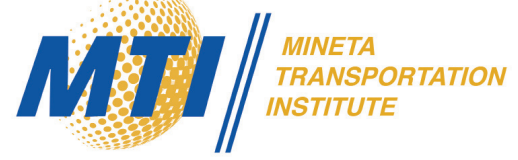

Numerical Investigations of Transient Wind Shear from Passing

Vehicles Near a Road Structure (Part I: Unsteady RANS Simulations)

Hamid Rahai, Ph.D.

Assma Begum, M.S.

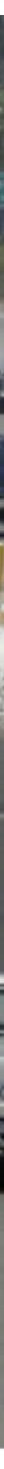

California State University
Transportation Consortium

CALIFORNIA STATE UNIVERSITY

LONG BEACH 


\section{Mineta Transportation Institute}

Founded in 1991, the Mineta Transportation Institute (MTI), an organized research and training unit in partnership with the Lucas College and Graduate School of Business at San José State University (SJSU), increases mobility for all by improving the safety, efficiency, accessibility, and convenience of our nation's transportation system. Through research, education, workforce development, and technology transfer, we help create a connected world. MTI leads the Mineta Consortium for Transportation Mobility (MCTM) funded by the U.S. Department of Transportation and the California State University Transportation Consortium (CSUTC) funded by the State of California through Senate Bill 1. MTI focuses on three primary responsibilities:

\section{Research}

MTI conducts multi-disciplinary research focused on surface transportation that contributes to effective decision making. Research areas include: active transportation; planning and policy; security and counterterrorism; sustainable transportation and land use; transit and passenger rail; transportation engineering; transportation finance; transportation technology; and workforce and labor. MTI research publications undergo expert peer review to ensure the quality of the research.

\section{Education and Workforce}

To ensure the efficient movement of people and products, we must prepare a new cohort of transportation professionals who are ready to lead a more diverse, inclusive, and equitable transportation industry. To help achieve this, MTI sponsors a suite of workforce development and education opportunities. The Institute supports educational programs offered by the Lucas Graduate School of Business: a Master of
Science in Transportation Management, plus graduate certificates that include High-Speed and Intercity Rail Management and Transportation Security Management. These flexible programs offer live online classes so that working transportation professionals can pursue an advanced degree regardless of their location.

\section{Information and Technology Transfer}

MTI utilizes a diverse array of dissemination methods and media to ensure research results reach those responsible for managing change. These methods include publication, seminars, workshops, websites, social media, webinars, and other technology transfer mechanisms. Additionally, MTI promotes the availability of completed research to professional organizations and works to integrate the research findings into the graduate education program. MTI's extensive collection of transportation-related publications is integrated into San José State University's world-class Martin Luther King, Jr. Library.

\section{Disclaimer}

The contents of this report reflect the views of the authors, who are responsible for the facts and accuracy of the information presented herein. This document is disseminated in the interest of information exchange. MTI's research is funded, partially or entirely, by grants from the California Department of Transportation, the California State University Office of the Chancellor, the U.S. Department of Homeland Security, and the U.S. Department of Transportation, who assume no liability for the contents or use thereof. This report does not constitute a standard specification, design standard, or regulation. 
Report 20-49

\section{Numerical Investigations of Transient Wind Shear from Passing Vehicles Near a Road Structure}

\section{Part I: Unsteady Reynolds-Averaged Navier-Stokes Simulations}

Hamid Rahai, Ph.D.

Assma Begum, M.S.

January 2021

A publication of the

Mineta Transportation Institute

Created by Congress in 1991

College of Business

San José State University

San José, CA 95192-0219 


\section{TECHNICAL REPORT DOCUMENTATION PAGE}

\begin{tabular}{|c|c|c|c|}
\hline $\begin{array}{l}\text { 1. Report No. } \\
20-49\end{array}$ & 2. Government Accession No. & \multicolumn{2}{|c|}{ 3. Recipient's Catalog No. } \\
\hline \multicolumn{2}{|c|}{ 4. Title and Subtitle } & \multicolumn{2}{|l|}{ 5. Report Date } \\
\hline \multicolumn{2}{|c|}{$\begin{array}{l}\text { Numerical Investigations of Transient Wind Shear from Passing Vehicles Near } \\
\text { a Road Structure } \\
\text { (Part I: Unsteady Reynolds-Averaged Navier-Stokes Simulations) }\end{array}$} & \multicolumn{2}{|c|}{ 6. Performing Organization Code } \\
\hline \multicolumn{2}{|c|}{$\begin{array}{l}\text { 7. Authors } \\
\text { Hamid Rahai, Ph.D., Assma Begum, M.S. }\end{array}$} & \multicolumn{2}{|c|}{$\begin{array}{l}\text { 8. Performing Organization Re- } \\
\text { port } \\
\quad \text { CA-MTI-1933 }\end{array}$} \\
\hline \multirow{2}{*}{\multicolumn{2}{|c|}{$\begin{array}{l}\text { 9. Performing Organization Name and Address } \\
\text { Mineta Transportation Institute } \\
\text { College of Business } \\
\text { San José State University } \\
\text { San José, CA 95192-0219 }\end{array}$}} & \multicolumn{2}{|c|}{ 10. Work Unit No. } \\
\hline & & \multicolumn{2}{|c|}{$\begin{array}{l}\text { 11. Contract or Grant No. } \\
\text { ZSB12017-SJAUX }\end{array}$} \\
\hline \multirow{2}{*}{\multicolumn{2}{|c|}{$\begin{array}{l}\text { 12. Sponsoring Agency Name and Address } \\
\text { State of California SB1 2017/2018 } \\
\text { Trustees of the California State University Sponsored Programs } \\
\text { Administration } \\
401 \text { Golden Shore, } 5 \text { th Floor } \\
\text { Long Beach, CA } 90802\end{array}$}} & \multicolumn{2}{|c|}{$\begin{array}{l}\text { 13. Type of Report and Period } \\
\text { Covered } \\
\quad \text { Final Report }\end{array}$} \\
\hline & & \multicolumn{2}{|c|}{ 14. Sponsoring Agency Code } \\
\hline \multicolumn{4}{|l|}{$\begin{array}{l}\text { 15. Supplemental Notes } \\
\text { DOI: } 10.31979 / \mathrm{mti} .2020 .1933\end{array}$} \\
\hline \multicolumn{4}{|c|}{$\begin{array}{l}\text { 16. Abstract } \\
\text { In this research, the authors performed unsteady numerical simulations of a moving Ahmed body under a freeway } \\
\text { overpass at different distances from the bridge columns in order to evaluate transient wind shear and the wind load } \\
\text { on these columns. Results have shown that when the vehicle is at } 0.75 \mathrm{~W} \text { distance from the bridge columns, an } \\
\text { unsteady wind speed of up to } 24 \mathrm{~m} / \mathrm{s} \text { is observed at the columns with a pressure coefficient difference of } 0.9 \text {. Here } \\
\mathrm{W} \text { is the width of the vehicle. The-se results indicate with an appropriate system for harnessing these wind energy } \\
\text { potentials, significant renewable electric power could be generated with zero carbon footprint. }\end{array}$} \\
\hline $\begin{array}{l}\text { 17. Key Words } \\
\text { Vehicle Aerodynamics, Vorticity, } \\
\text { Wind Load, Ahmed Body, Wind } \\
\text { Shear }\end{array}$ & \multicolumn{3}{|c|}{$\begin{array}{l}\text { 18. Distribution Statement } \\
\text { No restrictions. This document is available to the public through } \\
\text { The National Technical Information Service, Springfield, VA } 22161\end{array}$} \\
\hline $\begin{array}{l}\text { 19. Security Classif. (of this report) } \\
\text { Unclassified }\end{array}$ & $\begin{array}{l}\text { 20. Security Classif. (of this page) } \\
\text { Unclassified }\end{array}$ & $\begin{array}{l}\text { 21. No. of Pages } \\
21\end{array}$ & 22. Price \\
\hline
\end{tabular}

FORM DOT F 1700.7 (8-72) 
Copyright (C) 2021

\title{
by Mineta Transportation Institute
}

All rights reserved.

DOI: $10.31979 / \mathrm{mti} .2020 .1933$

\author{
Mineta Transportation Institute \\ College of Business \\ San José State University \\ San José, CA 95192-0219 \\ Tel: (408) 924-7560 \\ Fax: (408) 924-7565 \\ Email: mineta-institute@sjsu.edu
}

$\underline{\text { transweb.sjsu.edu/research/1933 }}$ 


\section{ACKNOWLEDGMENTS}

Funding for this research was provided by the State of California SB1 2019/2020 through the Trustees of the California State University (Agreement \# ZSB12017-SJAUX) and the California State University Transportation Consortium. The authors thank Editing Press for editorial and graphic design services, as well as MTI staff, including Executive Director Karen Philbrick, Ph.D.; Deputy Executive Director Hilary Nixon, Ph.D.; and Executive Administrative Assistant Jill Carter. 


\section{CONTENTS}

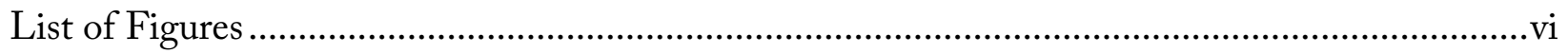

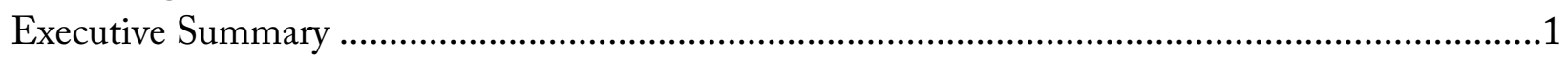

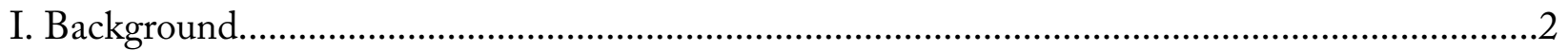

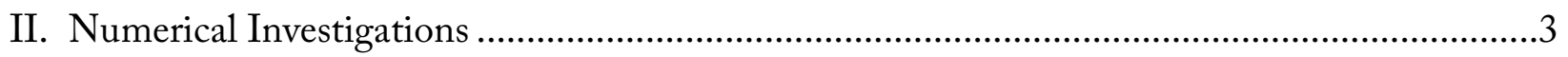

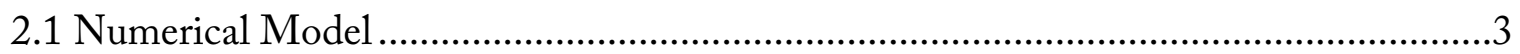

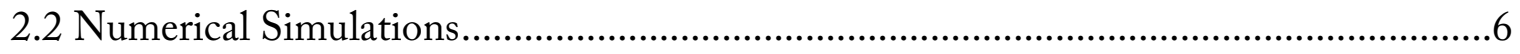

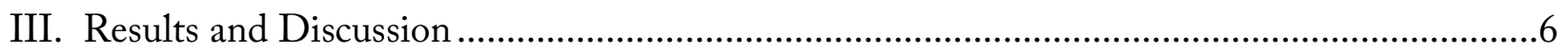

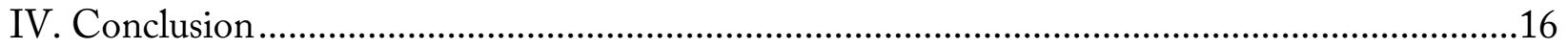

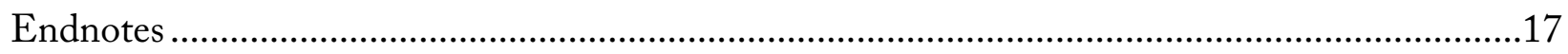

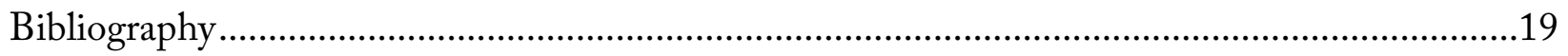

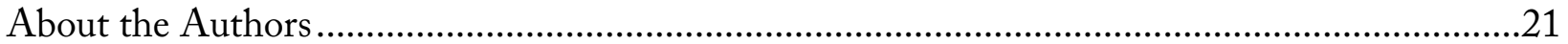




\section{LIST OF FIGURES}

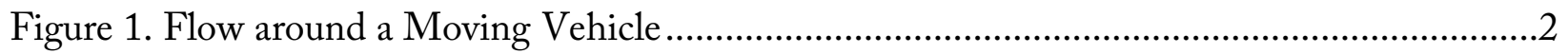

Figure 2. Top, Back, and Side Views of the Bridge Columns along with the Ahmed Body ….....4

Figure 3. Computational Grids, Stationary, and Overset Grids ...................................................

Figure 4. Contours of Mean Pressure at Four Different Time Steps

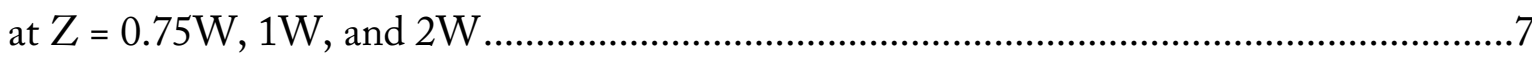

Figure 5. Contours of Mean Velocity at Four Different Time Steps

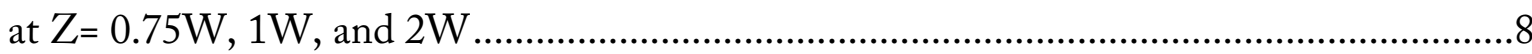

Figure 6. Contours of Mean Vorticity at Four Different Time Steps

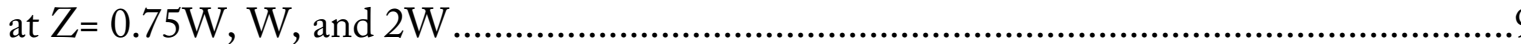

Figure 7. Contours of Turbulent Kinetic Energy (TKE) at Four Different Time Steps

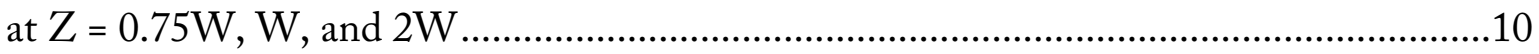

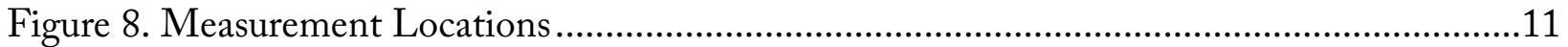

Figure 9. Frozen Contours of Mean Velocity for Planes Perpendicular to the Vehicle Direction at Different Locations for Three Spanwise Distances of $2 \mathrm{~W}, 1 \mathrm{~W}$, and $0.75 \mathrm{~W}$ from the Columns

Figure 10. Frozen Contours of Pressure Coefficient for Planes Perpendicular to the Vehicle Direction at Different Locations for Three Spanwise Distances of $2 \mathrm{~W}, 1 \mathrm{~W}$, and $0.75 \mathrm{~W}$ from the Columns.

Figure 11. Vector Plots of Mean Velocity for Planes Perpendicular to the Vehicle Direction at Different Locations for Three Direct Distances of $2 \mathrm{~W}, 1 \mathrm{~W}$, and $0.75 \mathrm{~W}$ from the Columns.

Figure 12. Frozen Contours of Vorticity for Planes Perpendicular to the Vehicle Direction at Different Locations for Three Direct Distances of $2 \mathrm{~W}, 1 \mathrm{~W}$, and $0.75 \mathrm{~W}$ from the Columns

Figure 13. Frozen Contours of Turbulent Kinetic Energy for Planes Perpendicular to theVehicle Direction at Different Locations for Three Direct Distances of $2 \mathrm{~W}, 1 \mathrm{~W}$, and $0.75 \mathrm{~W}$ from the Columns. 


\section{Executive Summary}

Among elements of an intelligent transportation system for autonomous vehicles are embedded sensors for vehicle-to-structure and vehicle-to-road communications. Continuous operation of these sensors requires local electric power, especially in remote areas. Electric power sources are also needed for the structural health monitoring system, that is, for detecting any structural damage, whether natural (i.e. earthquake) or manmade (i.e. accident). Here we are providing results of part I of our unsteady numerical investigations for a generic vehicle (Ahmed body) passing under a freeway overpass at different distances from the side bridge columns. The study aimed at understanding the wind load on the bridge columns and wind energy potential generated from the passing vehicles at different distances from the bridge columns under a typical freeway overpass that could be used for generating electric power. Results have shown that when the vehicle is at $0.75 \mathrm{~W}$ distance from the bridge columns, an unsteady wind speed of up to $24 \mathrm{~m} / \mathrm{s}$ is observed at the columns with a pressure coefficient difference of 0.9 . Here $\mathrm{W}$ is the width of the vehicle. These results indicate with an appropriate system for harnessing these wind energy potentials, significant renewable electric power could be generated with zero carbon footprint. 


\section{Background}

According to the US Department of Transportation, ${ }^{1}$ in 2017, the total highway vehicle-miles travelled was estimated at 3,212,347 with the light duty vehicles, short-wheel-base accounted for $2,220,801$ and trucks at 181,490. These data indicate the potential of energy generated on a daily basis by vehicles' travel which has not been captured for electric power generation. With the advancement in autonomous vehicles, a high precision global navigation satellite system (GNSS) in conjunction with local sensors for position attitude and navigation will provide accurate vehicle positioning as it moves through the freeways and highways. An autonomous vehicle must be able to sense its position, navigate itself toward a destination, and avoid obstructions (vehicles, freeway infrastructures, etc.). Road sensors could be critical elements in maintaining navigation. Local power generated from passing vehicles will provide the prospect for independent power generation for road sensors.

Slipstream is the transient airflow around a moving vehicle. It is highly turbulent and is divided into four regions as depicted in Figure 1. The nose region characterized by a peak in pressure along the stagnation streamline, the boundary region where boundary layer growth is observed along the length of the vehicle, the tail or near wake region where there are shear layer separations with periodic streamwise vortices, and finally the far wake region where gradual decay of air velocity is observed.

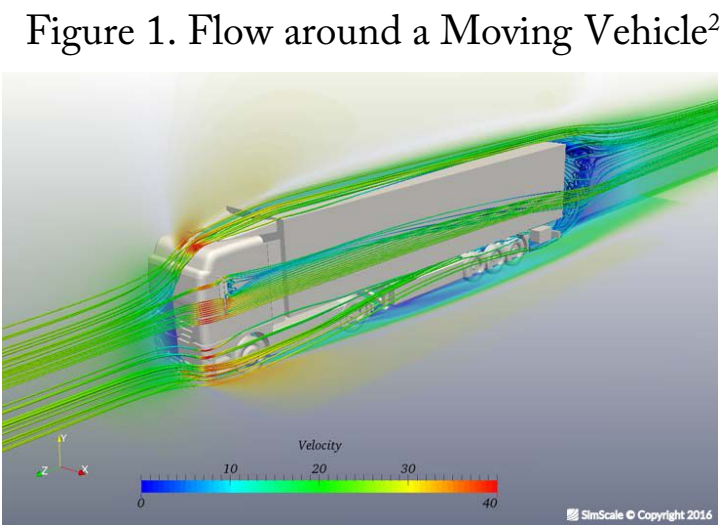

Previous investigations of the slipstream of moving trains, ${ }^{3-7}$ either on a scaled model or on a full scale, have shown that ahead of the nose, there are peak velocities that are shape-dependent, the higher the blockage the nose imposes, the larger the peak velocity. Along the body of the train, there are regions of zero, positive, and negative pressures that are related to the gap spacing between the loaded containers for the freight trains and inter-carriage for the passenger trains. The spacing creates large turbulent scales which for the freight trains estimated to be between $3 \mathrm{~m}-7 \mathrm{~m}$, and smaller turbulent scales within the boundary layer.

The tail region initially experiences a negative peak pressure, followed by a positive peak pressure, which is much smaller in magnitude than the peak pressure observed upstream of the nose region. 
Here, the tail shape has a great impact on the magnitude of the pressure peaks. Finally, in the far wake region, the pressure differential approaches zero and the air velocity is the same as the ambient air condition.

Other investigations ${ }^{8-11}$ on the flow around vehicles and bluff objects have shown their aerodynamic details with and without crosswind.

Studies on loads induced on road signs (roadside-mounted or over hanged) by vehicle-induced gusts $^{12,16}$ have provided important results as related to the effects of vehicles' shape and length, distance from the sign, and the size of the sign, on the magnitude of the load imposed. Force induced on road signs is proportional to the dynamic pressure, vehicle's frontal area, passing distance, and a friction coefficient which is defined in terms of a universal load curve. The forces generated from passing vehicles are due to static pressure variations near the moving vehicles, the larger the variations, the larger the forces. Also, the pedestrian barriers and signs mounted at higher than $2 \mathrm{~m}$ elevation experience a relatively constant force. While sign shape does not affect the imposed force, sign edging with frames increases it. These results indicate that as a vehicle passes; initially there is a large peak in induced force from the generated wind shear, which subsides to a smaller value with the passing of the vehicle. When the area is large, the forces are less, leading to reduced variations in flow-induced shock and vibration.

The study aimed at understanding details of wind shear from passing vehicles under the freeway overpasses, before conducting performance optimization for an innovative wind harnessing geometry and system, constitute of an optimized guide-vane enclosure and a high-efficiency vertical axis wind turbine for a fully functional model to capture wind energy from passing vehicles for local electric power generation. Our previous investigations ${ }^{17-19}$ have resulted in the development of a wind turbine system that has been tested in urban areas for capturing local wind energy for generating electricity. Based on the results of the proposed investigation, provided the wind shear generated from the passage of vehicles is strong and sufficient for electric power generation, a system utilizing the existing high-efficiency vertical axis wind turbine will be developed for installation under the freeway overpasses for generating electricity from passing vehicles.

\section{Numerical Investigations}

\subsection{Numerical Model}

An Ahmed body was used as a vehicle for our simulations. The Ahmed body has been used extensively for research into applications of new concepts in vehicle aerodynamics. ${ }^{20}$ Figures 2 and 3 show the Ahmed body and the bridge columns models along with the computational grid. The Ahmed body had dimensions of $1.62 \mathrm{~m}$ height $(\mathrm{H}), 5 \mathrm{~m}$ length $(\mathrm{L})$, and $1.86 \mathrm{~m}$ width $(\mathrm{W})$ with 
a hatchback rear at 35 degrees slope angle from the top, starting at $4.14 \mathrm{~m}$ from the vehicle's front. These dimensions are comparable to a small passenger van/SUV. The vehicle was spaced at 0.28 $\mathrm{m}$ above the road.

The control volume for the computational domain that encompasses the bridge has dimensions of $\mathrm{X}=30 \mathrm{~m}, \mathrm{Y}=11.25 \mathrm{~m}$, and $\mathrm{Z}=14.5 \mathrm{~m}$ with a grid size of $0.0375 \mathrm{~m}$. Here $\mathrm{X}$ is the direction of the vehicle, $\mathrm{Y}$ is the perpendicular distance and $\mathrm{Z}$ is the spanwise direction (across the road). The overpass bridge had a height of about $6.2 \mathrm{~m}$. The blockage ratio, the ratio of the projected area of the Ahmed body to the projected area of the bridge underpass was less than $3 \%$.

An overset grid known as Chimera or overlapping techniques was used to generate the grids for the simulations. It provides better control of the mesh generation and it has been used for unsteady simulations of moving objects as in the case of a moving vehicle. Figure 4 shows the two grids. For the entire computational domain, a hybrid mesh with an unstructured polyhedral grid was used, and for the moving vehicle away from the wall and a structured 15-layer hexahedral grid near the wall was used. The first grid point near the Ahmad body surface was at $0.025 \mathrm{~mm}$ and in the farfield, the maximum grid size was $0.1 \mathrm{~m}$. The growth rate between the near and far-fields was 1.3. The grid dependency test was performed using the vehicle's drag coefficient. Less than 5\% variation in drag coefficient was found when the number of cells exceeded 3 million and thus the number of cells was set at 3.5 million. For the unsteady simulations where the overset grid was used the cell number was at 14 million.

Simulations were performed for the moving vehicle having distances of $0.75 \mathrm{~W}, 1 \mathrm{~W}$, and $2 \mathrm{~W}$ away from the column rows. Here $\mathrm{W}$ is the width of the vehicle.

Figure 2. Top, Back, and Side Views of the Bridge Columns along with the Ahmed Body

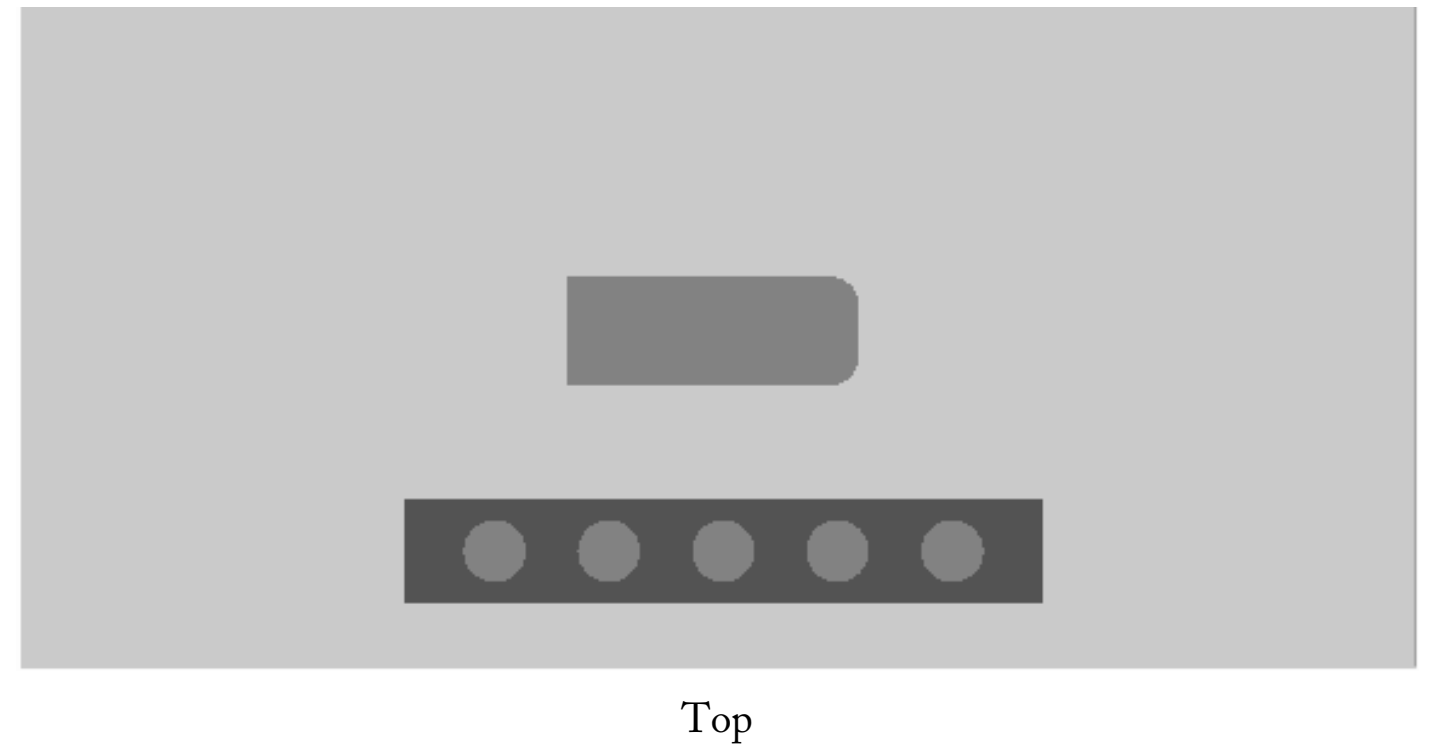


Figure 2. (continued from previous page)

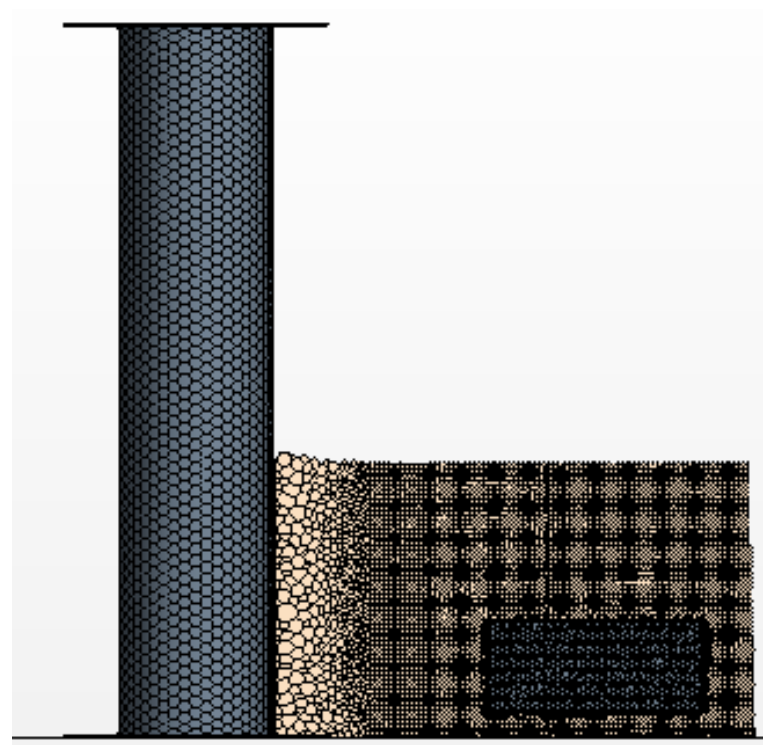

Back

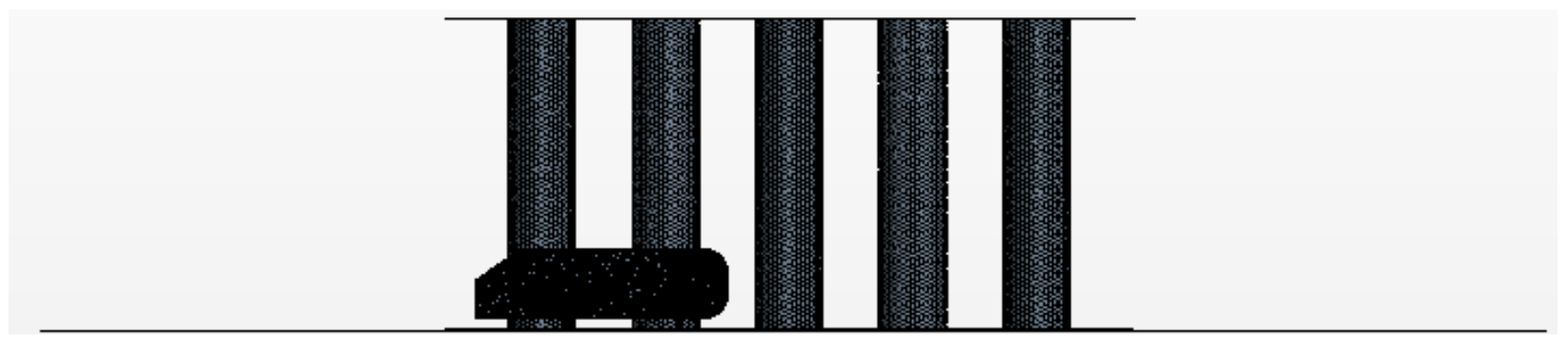

Side

Figure 3. Computational Grids, Stationary, and Overset Grids

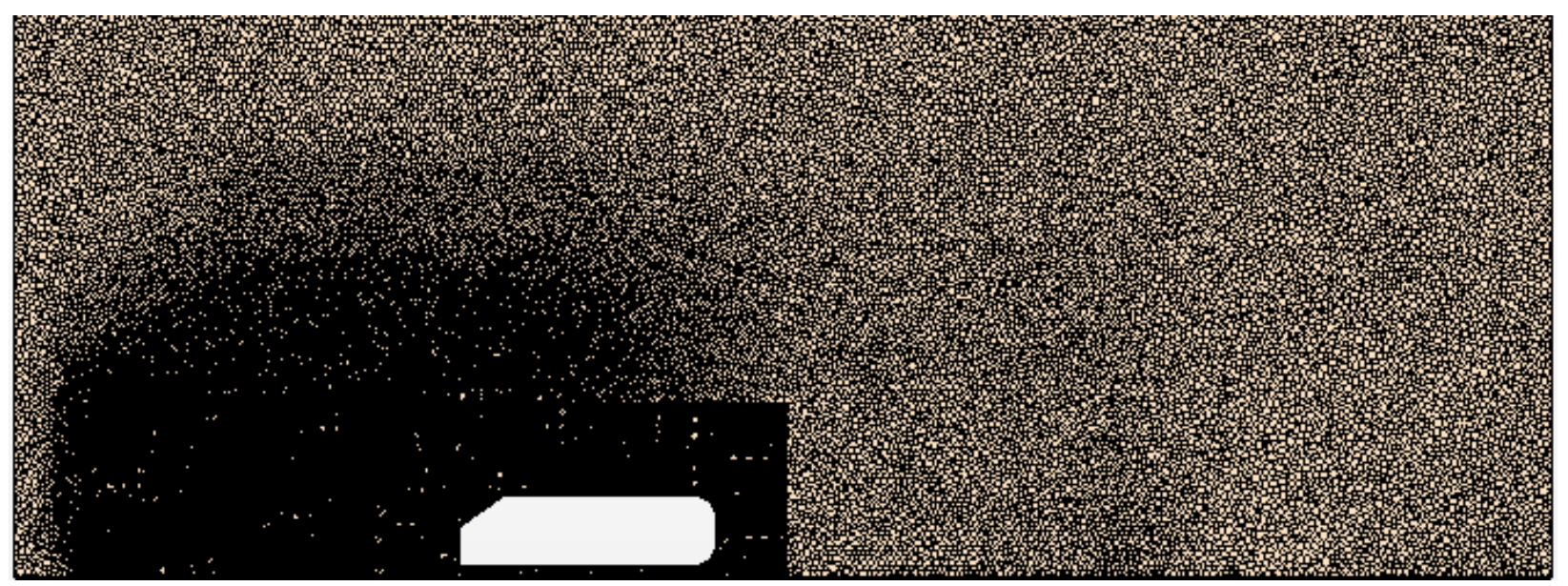




\subsection{Numerical Simulations}

Three-dimensional incompressible unsteady Reynolds-Averaged Navier-Stokes (U-RANS) equations were solved, using the shear stress transport (SST) $k^{-} \omega$ turbulence model. The density was constant. The freestream mean velocity in the axial direction was $23 \mathrm{~m} / \mathrm{sec}$. which corresponds to a Reynolds number based on an equivalent diameter based on the project vehicle area of $2.9 \times 10^{6}$. The computational fluid dynamics software Star CCM+ from Siemens on a Linux-based high-performance computing platform with 84 cores were used for all the simulations. Between 150-220 hours of computational time were used for each simulation and the results presented here are starting $11 \mathrm{sec}$. after the start of each simulation with a time step $\Delta t=0.0007 \mathrm{sec}$.

\section{Results and Discussion}

Figures 4 and 5 show contours of mean pressure and axial mean velocity around the vehicle as it moves past the columns at three spanwise distances $\mathrm{Z}$ of $0.75 \mathrm{~W}, 1 \mathrm{~W}$, and $2 \mathrm{~W}$. For all cases studied, the pressure is high at the front of the vehicle (the front stagnation point), reduces to a negative pressure due to the flow acceleration, increases slightly along the body of the vehicle, but still at negative pressure, due to a slight flow deceleration, remains negative at the back of the vehicle with pressure recovery downstream. The vehicle experiences significant pressure drag with an approximate pressure drag coefficient of 0.28 . Here the drag coefficient was calculated as:

$$
C_{\text {Dpressure }}=\frac{\nabla p}{\frac{1}{2} \rho U_{\infty}^{2} A_{\text {projected }}}
$$

Here $\nabla p, \rho$, and $U_{\infty}$ are respectively pressure differential across the vehicle, air density, and free stream mean velocity, and $A_{\text {projected }}$ of the vehicle. The calculated drag coefficient is comparable to the published drag coefficient of approximately 0.3 for the Ahmed body which includes both pressure and viscous drag.

As the vehicle gets closer to the columns, a region of high pressure is formed upstream of the vehicle and the columns. The shorter the distance, the higher the pressure force. The maximum force experienced is approximately 200 pascals (pa).

The variation in the mean velocity is inversely proportional to the variation in static pressure, beginning with zero velocity at the stagnation point and accelerating to an approximate value of $30 \mathrm{~m} / \mathrm{sec}$. as the flow moves toward the body, then reduces slightly along the body, before separating and shedding vortices into the wake. In all cases, velocity is zero on the vehicle's body due to the no-slip boundary condition. 
Flow separation in the wake creates oscillatory flow, ejecting high momentum fluids downstream. Significant oscillatory flow is seen at $1 \mathrm{~W}-2 \mathrm{~W}$ downstream, beyond which the wake expands and dissipates. At $6 \mathrm{~W}$ downstream, the wake width has expanded to approximately $6 \mathrm{~W}$.

As the vehicle gets closer to the columns, high momentum oscillatory flow impinges on the columns. It is interesting to note that significant expansion of the wake is seen downstream, beyond the first column for $\mathrm{Z}=0.75 \mathrm{~W}$ and $1 \mathrm{~W}$ which indicates a potential source for capturing wind energy at these locations.

Figure 4. Contours of Mean Pressure at Four Different Time Steps at $Z=0.75 \mathrm{~W}, 1 \mathrm{~W}$, and $2 \mathrm{~W}$

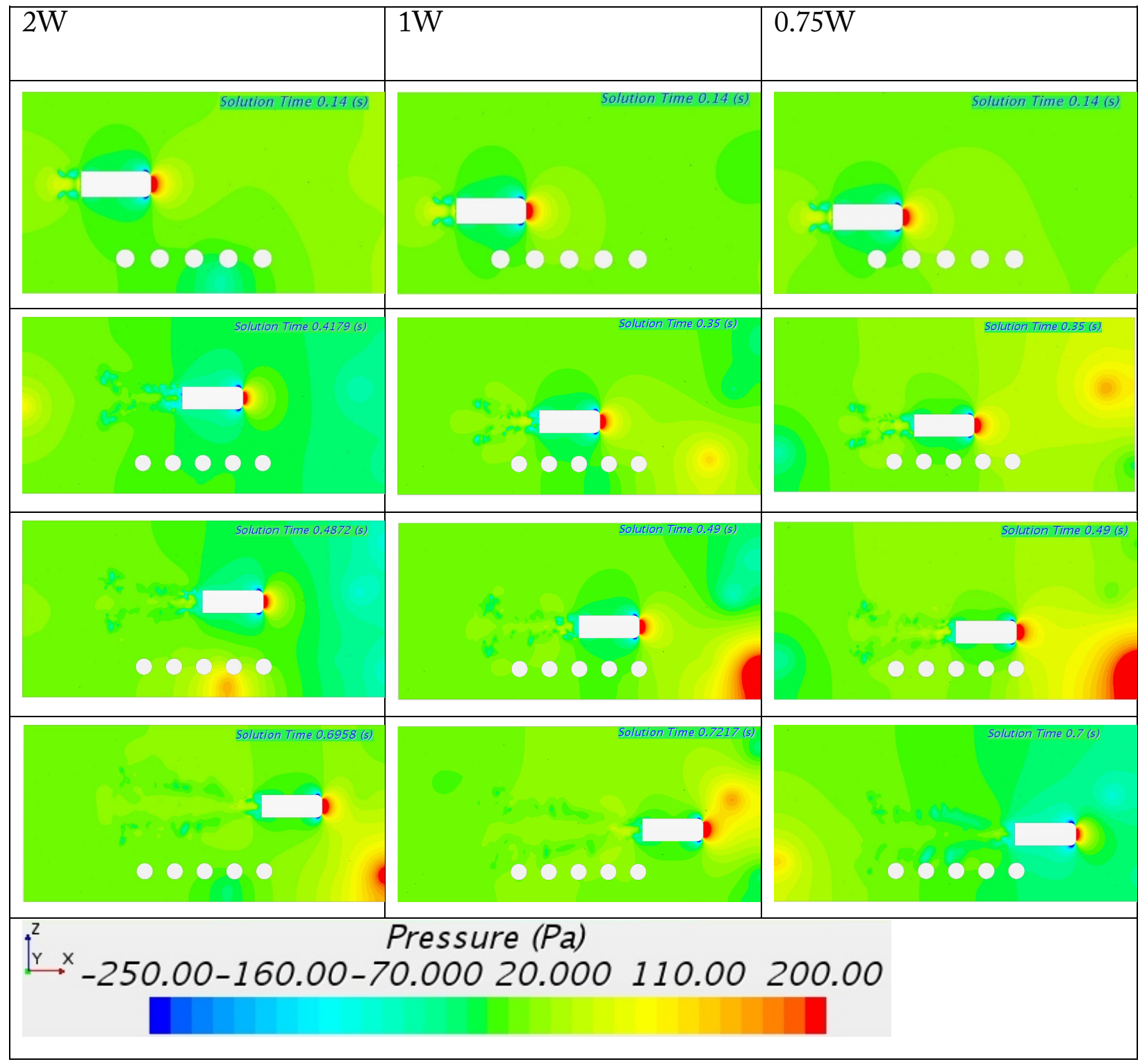


Figure 5. Contours of Mean Velocity at Four Different Time Steps at $\mathrm{Z}=0.75 \mathrm{~W}, 1 \mathrm{~W}$, and 2W

\begin{tabular}{|c|c|c|}
\hline $2 \mathrm{~W}$ & $1 \mathrm{~W}$ & $0.75 \mathrm{~W}$ \\
\hline 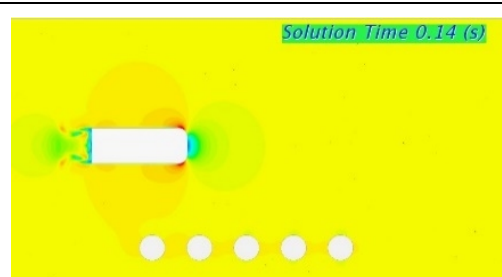 & 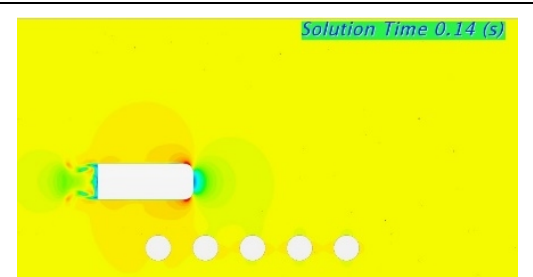 & $\sqrt{100}$ \\
\hline 00000 & $=00000$ & Solutrion Time 0.35 (s) \\
\hline 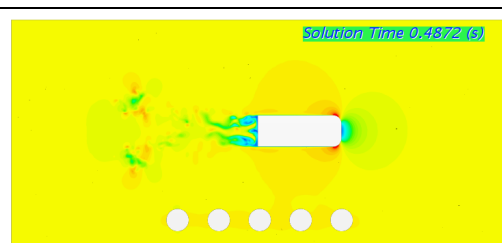 & 3i. & 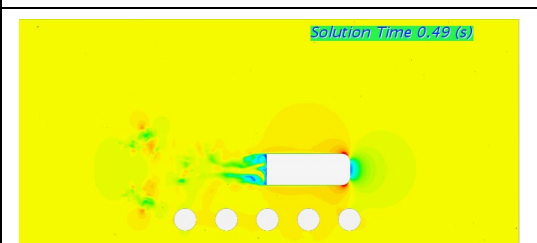 \\
\hline $3+\frac{1}{30}$ & 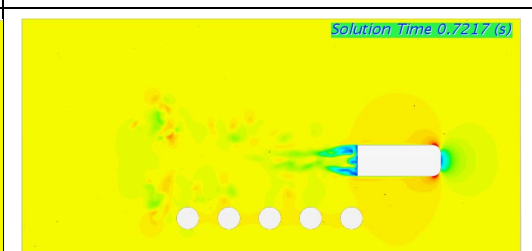 & 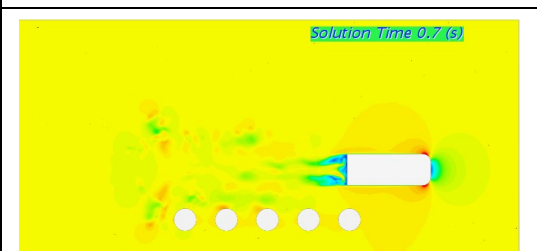 \\
\hline $\begin{array}{l}\text { Velocity in Referencel } \\
\times 0.000006 .0000\end{array}$ & $\begin{array}{l}\text { rame for Translation: } M \\
12.000 \quad 18.000 \quad 24.00\end{array}$ & $\begin{array}{l}\text { agnitude }(\mathrm{m} / \mathrm{s}) \\
030.000\end{array}$ \\
\hline
\end{tabular}

Figures 6 and 7 show contours of vorticity and turbulent kinetic energy (TKE) at four different time steps for $Z=0.75 \mathrm{~W}, 1 \mathrm{~W}$, and $2 \mathrm{~W}$. The vehicle's near wake experiences a significant increase in vorticity and $T K E$ which are enhanced as the vehicle passes the columns. At $Z=0.75$, with the passing of the vehicle, the vortices impinging on the columns and increased TKE is observed adjacent and downstream of the columns. These results again confirm that just before column 1 and most likely upstream of the columns 4 are two potential areas with increased mean velocity and vorticity that could be used for harnessing wind energy from the passing vehicles. They also point to the fact that any kind of detecting sensors placed on the columns should be designed to sustain these oscillatory loads, without compromising their performances. 
Figure 6. Contours of Mean Vorticity at Four Different Time Steps at $\mathrm{Z}=0.75 \mathrm{~W}, \mathrm{~W}$, and 2W

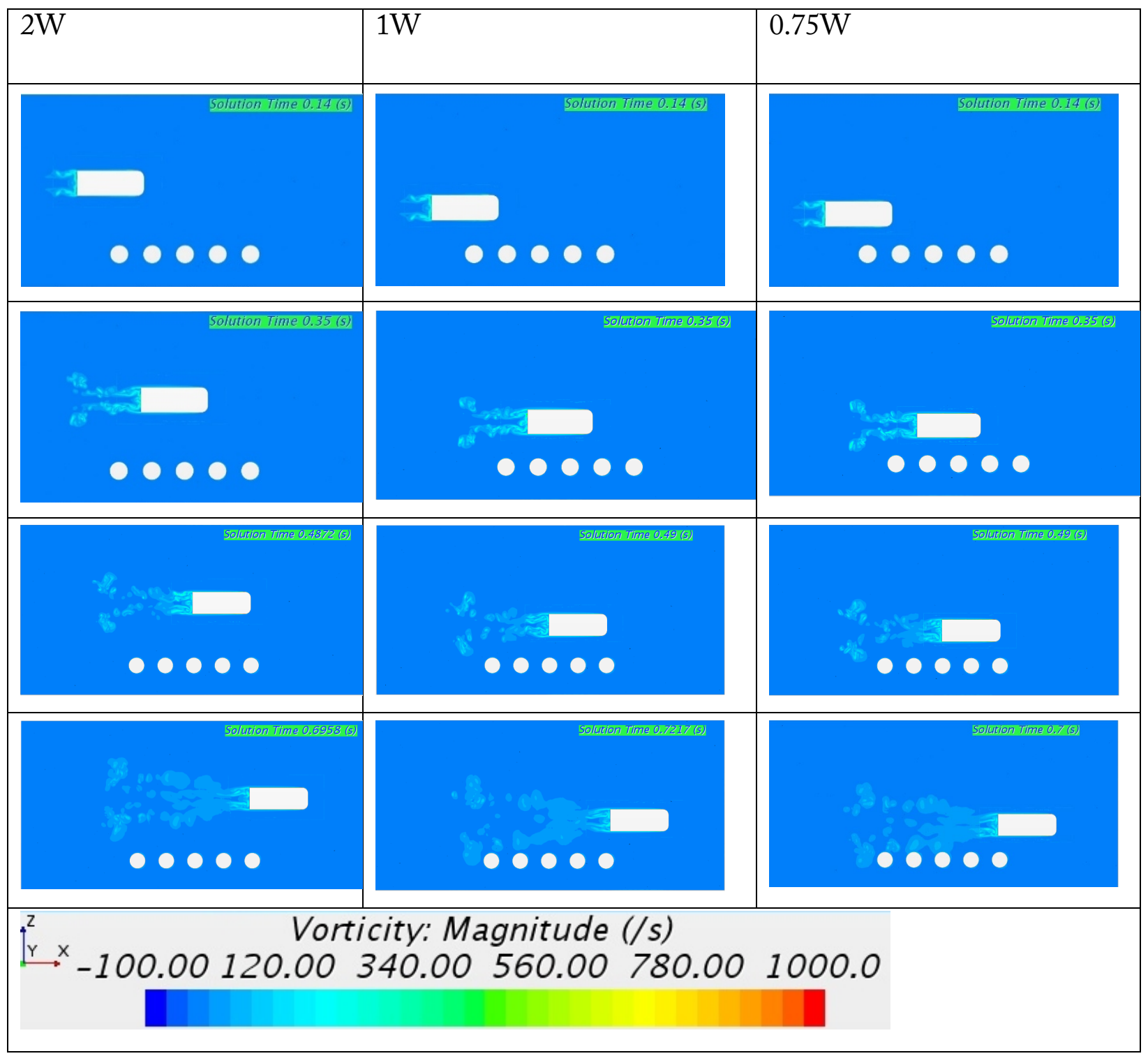


Figure 7. Contours of Turbulent Kinetic Energy (TKE) at Four Different

Time Steps at $\mathrm{Z}=0.75 \mathrm{~W}, \mathrm{~W}$, and $2 \mathrm{~W}$

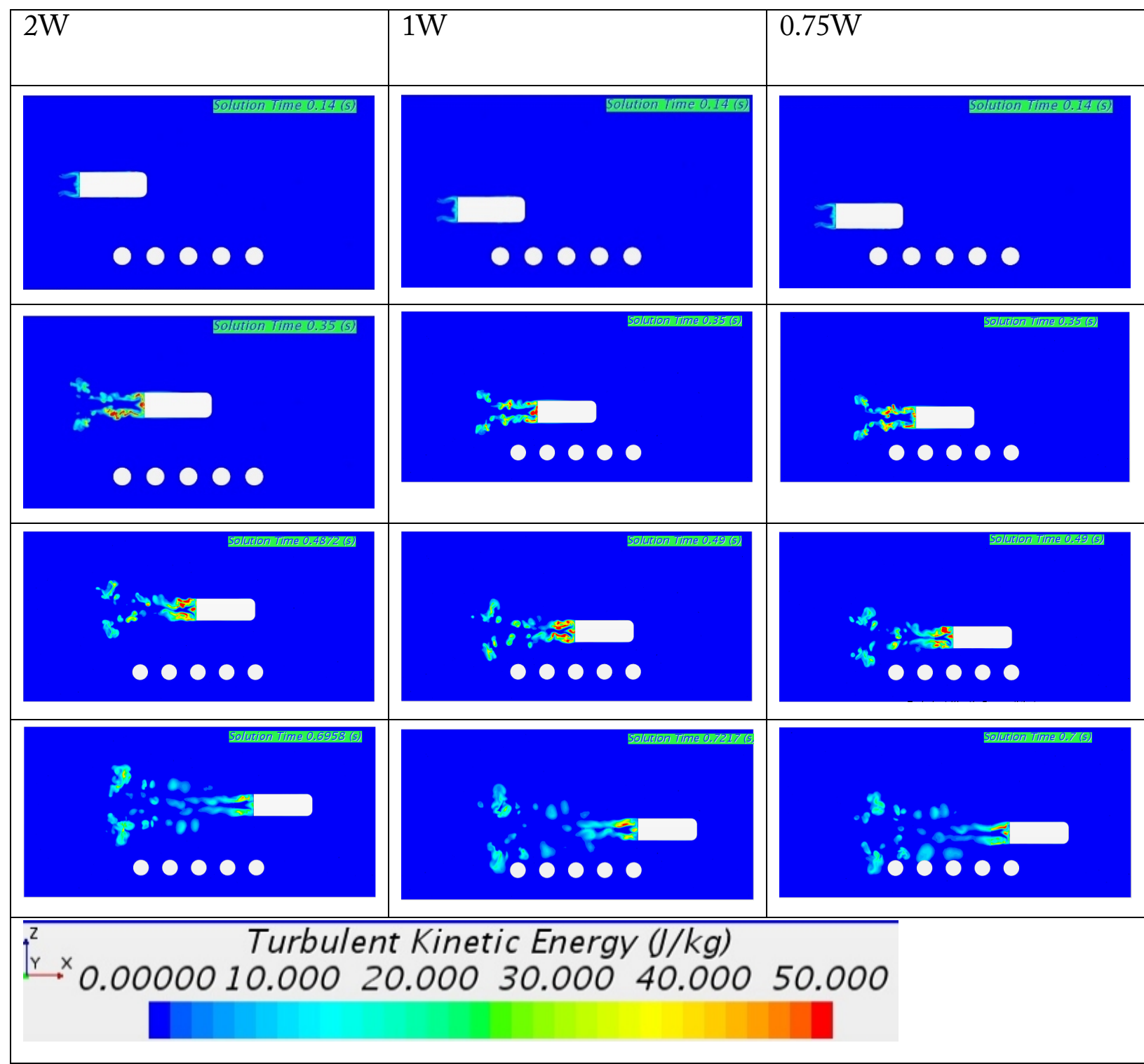

To assess the spanwise variations of the wind shear from the passing vehicle, contours of mean velocity, mean pressure coefficient, vorticity, and turbulent kinetic energy, along with velocity vector have been presented at perpendicular planes to the vehicle directions. The contours were obtained with the vehicle being at $0.75 \mathrm{~W}, 1 \mathrm{~W}$, and $2 \mathrm{~W}$ distances from the bridge columns. Figure 8 show the vehicle and the columns and measurement locations.

The pressure coefficient was calculated as follows where the reference static pressure was zero:

$$
C_{p}=\frac{\nabla p}{\frac{1}{2} \rho U_{\infty}^{2}}
$$


Figure 8. Measurement Locations

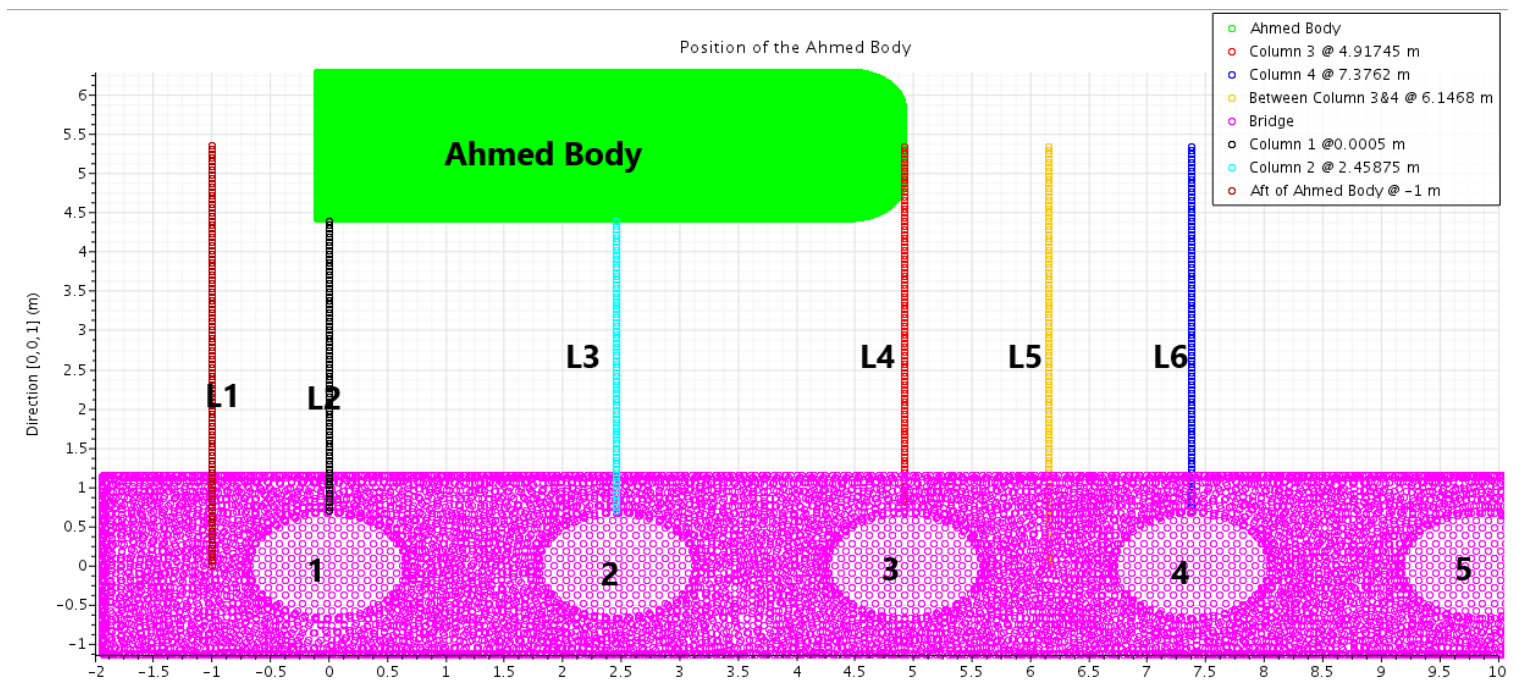

Figures 9-12 show frozen contours of mean velocity, pressure coefficient, vorticity, and turbulent kinetic energy (TKE), along with mean velocity vectors at different spanwise locations when the vehicle is at $2 \mathrm{~W}, 1 \mathrm{~W}$, and $0.75 \mathrm{~W}$ away from the columns. Here $\mathrm{L} 1$ is the near-wake of the vehicle, L2 is right at the back of the vehicle, L3 corresponds to the vehicle mid-section, and L4 is right in front of the vehicle aligned with the front stagnation location. For all spanwise distances, mean velocity is non-uniform with areas of low and high-velocity corresponding to the shear flows separating from the vehicle and penetrating the low-pressure region of the wake. The variations are more pronounced at the back of the vehicle where the cavity region acts as a sink attracting unsteady flow penetration into this region.

Significant velocity gradients are seen on the top of the vehicle where the flow is separating from the body due to the slanted surfaces where the velocity goes from around $10 \mathrm{~m} / \mathrm{s}$ to as high as 30 $\mathrm{m} / \mathrm{s}$.

Variations of the pressure coefficient are in opposite direction to the corresponding variations of the mean velocity; it increases when velocity decreases and vice versa.

At L2\&L3, for $0.75 \mathrm{~W}$ distance, the wind generated from the vehicle reaches the columns with wind speed reaching approximately $24 \mathrm{~m} / \mathrm{s}$ which is significant wind energy in generating electricity. The corresponding difference in the pressure coefficient is nearly 0.9. Depending on what kind of mechanism is used to generate electricity, whether it is a diaphragm that oscillated from passing vehicles or a low friction vertical axis wind turbine, the wind energy potential could provide sustained electricity for measurement and monitoring devices, lightening which increases safety and security, and energy security with a reduced carbon footprint. 
Figure 9. Frozen Contours of Mean Velocity for Planes Perpendicular to the Vehicle Direction at Different Locations for Three Spanwise Distances of 2W, $1 \mathrm{~W}$, and $0.75 \mathrm{~W}$ from the Columns

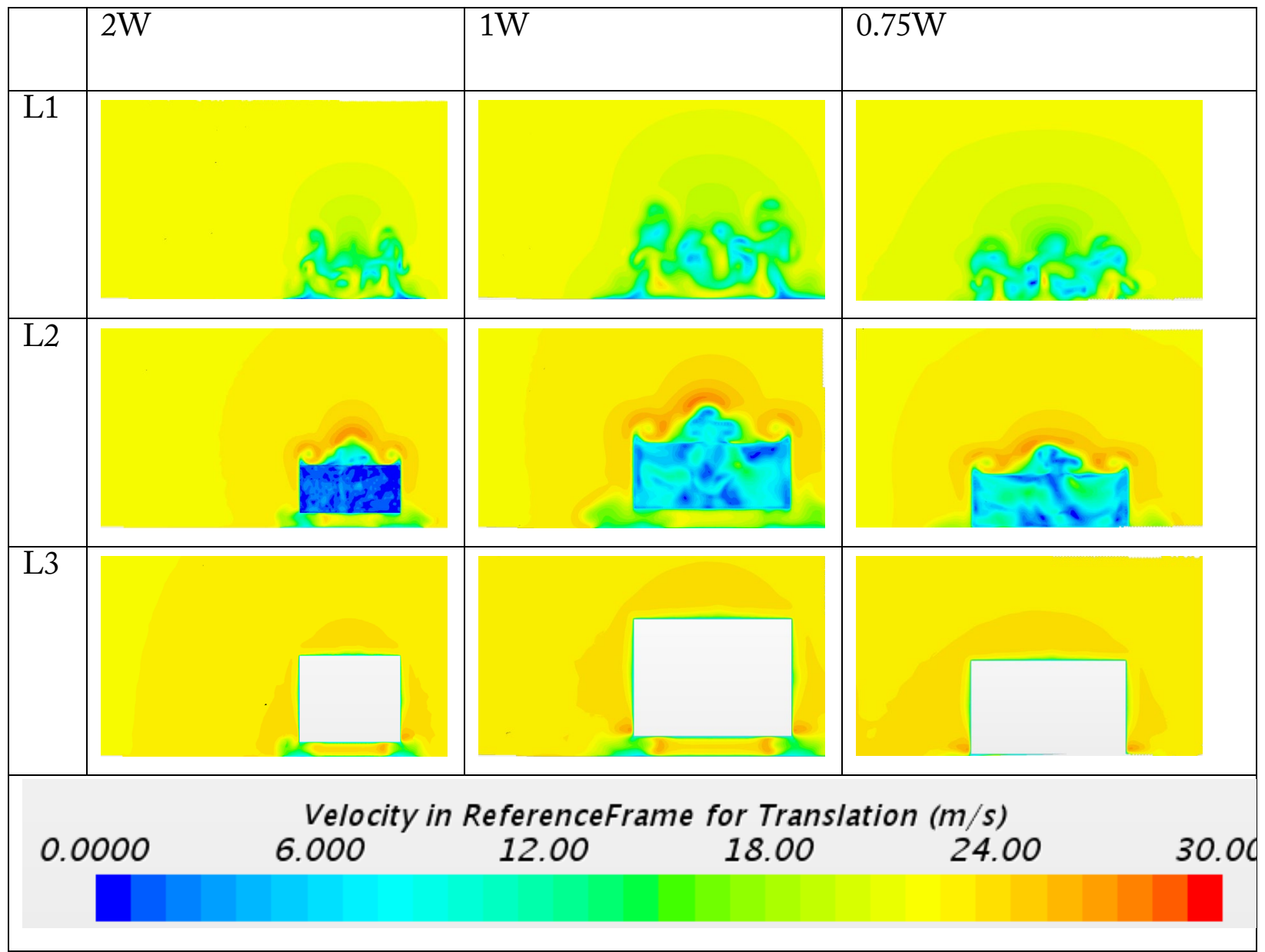


Figure 10. Frozen Contours of Pressure Coefficient for Planes Perpendicular to the Vehicle Direction at Different Locations for Three Spanwise Distances of 2W, 1W, and 0.75W from the Columns

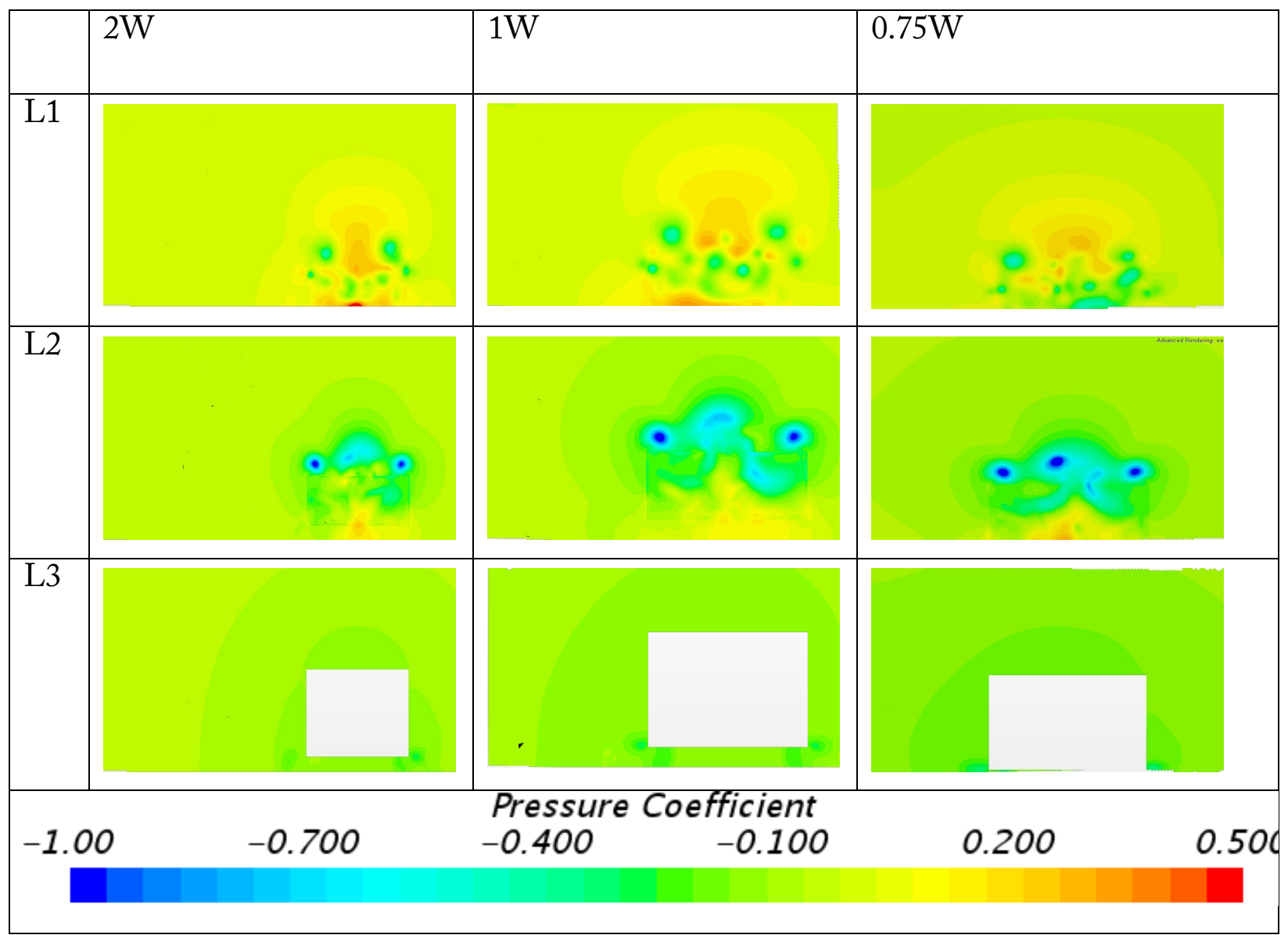


Figure 11. Vector Plots of Mean Velocity for Planes Perpendicular to the Vehicle Direction at Different Locations for Three Direct Distances of 2W, 1W, and 0.75W from the Columns

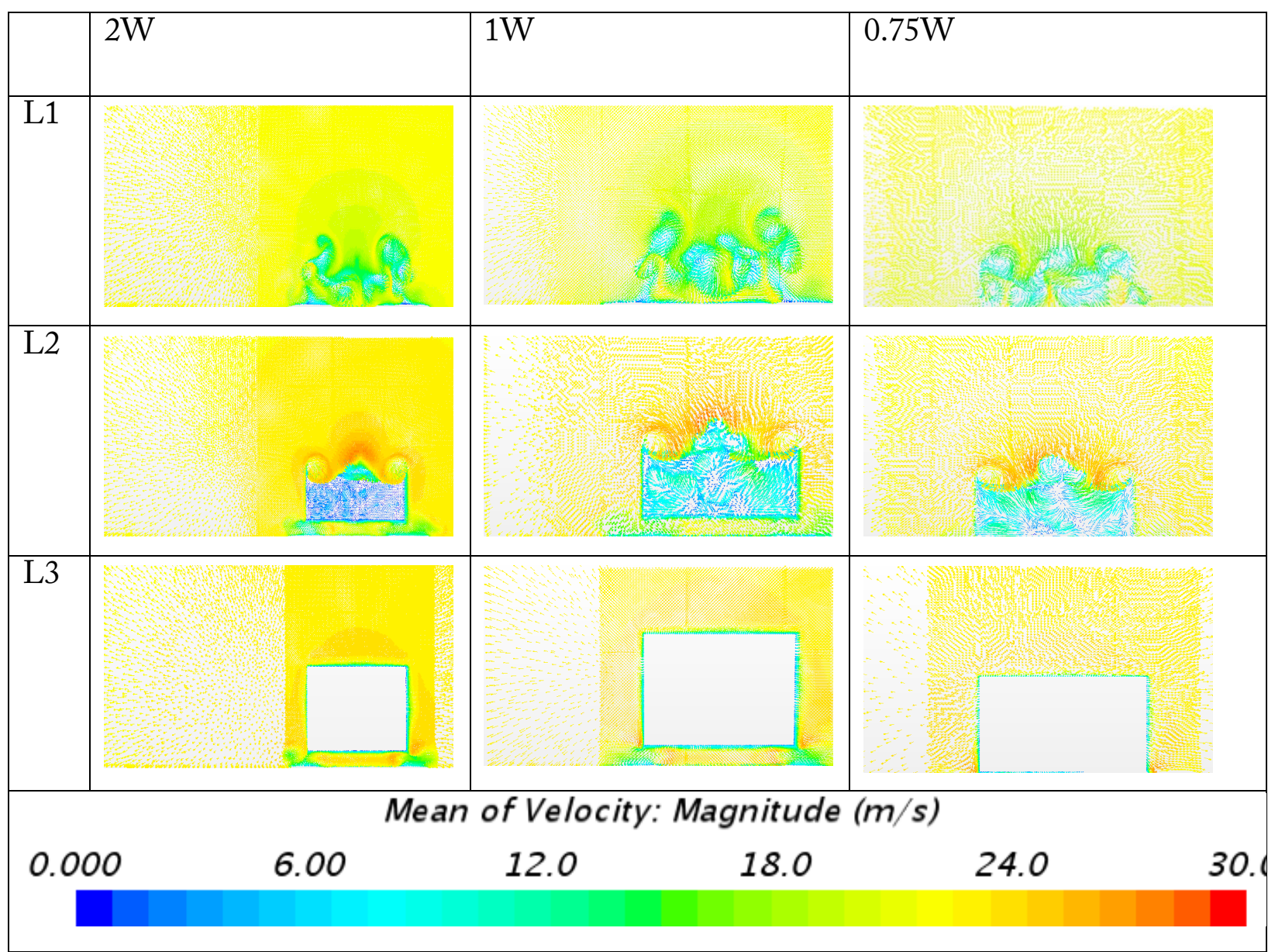

With increasing distance from the columns, significant changes in vorticity are observed. Vorticity is calculated from:

$$
\omega_{z}=\frac{\partial V}{\partial x}-\frac{\partial U}{\partial y}
$$

Here $\omega_{z}$ is vorticity in the plane perpendicular to the vehicle direction, $\mathrm{U}$ and $\mathrm{V}$ are axial and vertical mean velocity, and $\mathrm{x}$ and $\mathrm{y}$ are axial and vertical directions. Results show with reduced distance between the vehicle and the columns, vorticity is reduced. Circulation is an integration of the vorticity in a plane and is a measure of fluid rotation. Reducing vorticity reduces fluid rotation which means the rotational flow is not prominent when the vehicle is close to the columns.

Vorticity generated at the back of the vehicle results in an increase in TKE which is high on the top and at the center wake. However, near the columns, TKE is nearly zero and thus at these locations normal turbulent stress is not significant. 
Figure 12. Frozen Contours of Vorticity for Planes Perpendicular to the Vehicle Direction at Different Locations for Three Direct Distances of 2W, 1W, and 0.75W from the Columns

\begin{tabular}{|c|c|c|c|}
\hline & $2 \mathrm{~W}$ & $1 \mathrm{~W}$ & $0.75 \mathrm{~W}$ \\
\hline $\mathrm{L} 1$ & & & \\
\hline $\mathrm{L} 2$ & & & \\
\hline L3 & & & \\
\hline-10 & 20.000 & $\begin{array}{cc}\text { Vorticity: } \text { Magnitude }(/ \mathrm{s}) \\
140.00 & 260.00\end{array}$ & 380.00 \\
\hline
\end{tabular}


Figure 13. Frozen Contours of Turbulent Kinetic Energy for Planes Perpendicular to the Vehicle Direction at Different Locations for Three Direct Distances of 2W, 1W, and 0.75W from the Columns

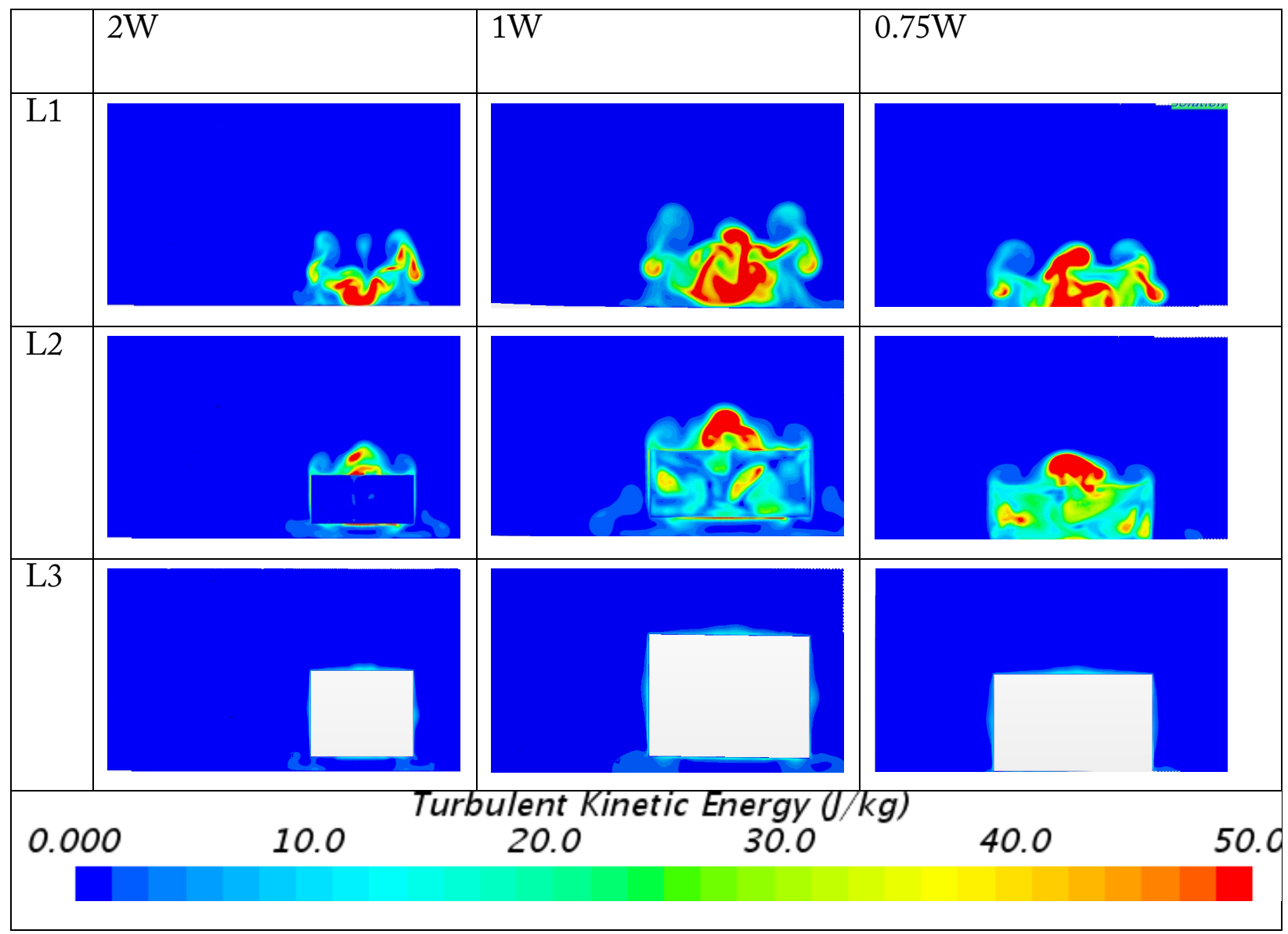

\section{Conclusion}

Unsteady numerical simulations of an Ahmed body passing under a freeway overpass at different distances from the side columns have been performed. The investigations have been performed for three vehicle distances to the bridge columns of $2 \mathrm{~W}, 1 \mathrm{~W}$, and $0.75 \mathrm{~W}$. Here $\mathrm{W}$ is the width of the vehicle. The goal of the investigation was to identify any wind energy potential from the passing of the vehicle that could be harnessed for generating electricity. Results indicate with the passing of the vehicle, oscillatory flow is generated which is significant when the vehicle is at $0.75 \mathrm{~W}$ from the columns. At this distance, the vorticity and TKE are reduced and thus turbulent normal stress and fluid rotation are minimized. The study shows with increased traffic, with an appropriate highefficiency wind capturing system, significant electrical power could be generated which could be used to power local monitoring sensors and lighting for safety and security. 


\section{Endnotes}

1 “U.S. Vehicle-Miles," U.S. Department of Transportation, Bureau of Transportation Statistics, accessed September 30, 2020, https://www.bts.gov/content/us-vehicle-miles.

${ }^{2}$ Rose McCallen, Fred Browand, and James Ross, eds, The Aerodynamics of Heavy Vebicles: Trucks, Buses, and Trains (Berlin: Springer, 2004).

3 David Soper, Christopher Baker, and Mark Sterling, "Experimental Investigation of the Slipstream Development around a Container Freight Train using a Moving Model Facility," Journal of Wind Engineering and Industrial Aerodynamics 135 (2014): 105-117.

${ }^{4}$ Chris Baker, "The Flow Around High-Speed Trains," Journal of Wind Engineering and Industrial Aerodynamics 98 (2010):277-98.

${ }^{5}$ C. J. Baker, "The Simulation of Unsteady Aerodynamic Crosswind Forces on Trains," Journal of Wind Engineering and Industrial Aerodynamics 98 (2010): 88-99.

${ }^{6}$ C. J. Baker, "Flow and Dispersion in Ground Vehicle Wake," Journal of Wind Engineering and Industrial Aerodynamics 15 (2001): 1031-1060.

${ }^{7}$ C. J. Baker, S. J. Dalley, T Johnson, A. Quinn, and N.G. Wright, "The Slipstream and Wake of a High-Speed Train," Proceedings of the Institution of Mechanical Engineers, Part F: Journal of Rail and Rapid Transit 215 (2001): 83-99.

${ }^{8}$ Haechon Choi, Jungil Lee, and Hyungmin Park. "Aerodynamics of Heavy Vehicles," Annual Review of Fluid Mechanics 46 (2014): 441-68.

${ }^{9}$ Mustafa Hammache, Mark Michaelian, and Fred Browand, Aerodynamic Forces on Truck Models, including Two Trucks in Tandem, UCB-ITS-PRR-2001-27 (Berkeley, CA: California Path Program, Institution of Transportation Studies, University of California, 2001), https://www.researchgate.net/publication/245227508_Aerodynamic_Forces_on_Truck_Models _Including_Two_Trucks_in_Tandem.

${ }^{10}$ P.W. Bearman, "Near Wake Flows behind Two- and Three-dimensional Bluff Bodies," Journal of Wind Engineering and Industrial Aerodynamics 69-71(1997): 33-54.

${ }^{11}$ P.W. Bearman, J.P. Davis, and J.K. Harvey, "Measurements of the Structure of Road Vehicle Wakes," International J. of Vehicle Design, SP3 (1983): 403-499. 
${ }^{12}$ B. Ruck and P. Lichtneger, Wind Loads on Flat Board and Walls Induced by Passing, Fachtagung "Lasermethodyn in der Strömungsmesstechnik," September 2014, https://galaev.org/images/Beitraege/Beitraege\%202014/pdf/14.pdf.

${ }^{13}$ Simone Salvadori, Tommaso Morbiato, Alessandro Mathana, and Enrico Fusto, "On the Characterization of Wind Profile Generated by Road Traffic," in Seventh International Colloquium on Bluff Body Aerodynamics and Applications (BBAA7): 1729-1741, Shanghai, China: September 26, 2012.

${ }^{14}$ A. D. Quinn, C. J. Baker, and N. G. Wright, "Wind and Vehicle Induced Forces on Flat PlatesPart I: Wind Induced Forces," Journal of Wind Engineering \& Industrial Aerodynamics 89 (2001): 811-823.

${ }^{15}$ A. D. Quinn, C. J. Baker, and N. G. Wright, "Wind and Vehicle Induced Forces on Flat PlatesPart II: Vehicle Induced Forces," Journal of Wind Engineering E Industrial Aerodynamics 89 (2001): 831-847.

${ }^{16}$ Philip M. Cali and Eugene E. Covert, "Experimental Measurements of the Loads Induced on an Overhead Highway Sign Structure by Vehicle-Induced Gusts," Journal of Wind Engineering and Industrial Aerodynamics 84 (2000): 87-100.

${ }^{17}$ Hamid R. Rahai and Hefazi, H., "Development of Optimum Design Configuration and Performance for Vertical Axis Wind Turbine," Final Report for Grant 0017, Energy Innovation Small Grant (EISG) Program, California Energy Commission, December 2002.

${ }^{18}$ Hamid R. Rahai and Hamid Hefazi, Vertical Axis Wind Turbine with Optimized Blade Profile, US Patent No. 7,393,177 B2, filed November 4, 2005, and issued July 1, 2008.

${ }^{19}$ Robert M. Plaskove, Courtlandt G. Miller, Hamid Hefazi, and Hamid R. Rahai, H.R. Wind Turbine Apparatus, US Patent No. 8,358,030, filed January 19, 2012, and issued January 22, 2013.

${ }^{20}$ J. Venning, D. L. Jacono, D. Burton, M. Thompson, and J. Sheridan, “ The Effect of Aspect Ratio on the Wake of the Ahmed Body," Experiments in Fluids 56 (2015). https://doi.org/10.1007/s00348-015-1996-5. 


\section{Bibliography}

Baker, C. "The Flow Around High-Speed Trains." Journal of Wind Engineering and Industrial 98 (2010): 277-98.

Baker, C. J. "The Simulation of Unsteady Aerodynamic Crosswind Forces on Trains." Journal of Wind Engineering and Industrial Aerodynamics 98 (2010): 88-99.

Baker, C.J., "Flow and Dispersion in Ground Vehicle Wake." Journal of Wind Engineering and Industrial Aerodynamics 15 (2001): 1031-1060.

Baker, C.J., S. J. Dalley, T. Johnson, A. Quinn, and N.G. Wright, "The Slipstream and Wake of a High-Speed Train." Proceedings of the Institution of Mechanical Engineers, Part F: Journal of Rail and Rapid Transit 215 (2001): 83-99.

Bearman, P.W. "Near Wake Flows behind Two- and Three-dimensional Bluff Bodies." Journal of Wind Engineering and Industrial Aerodynamics 69-71(1997): 33-54.

Bearman, P.W., Davis, J.P., and Harvey, J.K. "Measurements of the Structure of Road Vehicle Wakes," International J. of Vehicle Design, SP3 (1983): 403-499.

Cali, Philip M., and Eugene E. Covert. "Experimental Measurements of the Loads Induced on an Overhead Highway Sign Structure by Vehicle-Induced Gusts." Journal of Wind Engineering and Industrial Aerodynamics 84 (2000): 87-100.

Choi, Haechon, Jungil Lee, and Hyungmin Park. "Aerodynamics of Heavy Vehicles.” Annual Review of Fluid Mechanics 46 (2014): 441-68.

Hammache, Mustafa, Mark Michaelian, and Fred Browand. Aerodynamic Forces on Truck Models, including two Trucks in Tandem. UCB-ITS-PRR-2001-27, California Path Program, Institution of Transportation Studies, University of California, Berkeley, October 2001. https://www.researchgate.net/publication/245227508_Aerodynamic_Forces_on_Truck_ Models_Including_Two_Trucks_in_Tandem.

McCallen, Rose, Fred Browand, and James Ross, eds. The Aerodynamics of Heavy Vehicles: Trucks, Buses, and Trains. Berlin: Springer, 2004.

Plaskove, Robert M., Courtlandt G. Miller, Hamid Hefazi, and Hamid R. Rahai, H.R. Wind Turbine Apparatus. US Patent No. 8,358,030, filed January 19, 2012, and issued January 22, 2013. 
Quinn, A.D., C. J. Baker, and N. G. Wright. "Wind and Vehicle Induced Forces on Flat PlatesPart I: Wind Induced Forces." Journal of Wind Engineering E Industrial Aerodynamics 89 (2001): 811-823.

Quinn, A.D., C. J. Baker, and N. G. Wright. "Wind and Vehicle Induced Forces on Flat PlatesPart II: Vehicle Induced Forces.” Journal of Wind Engineering \& Industrial Aerodynamics 89 (2001): 831-847.

Rahai, Hamid R. and Hamid Hefazi, "Development of Optimum Design Configuration and Performance for Vertical Axis Wind Turbine," Final Report for Grant 0017, Energy Innovation Small Grant (EISG) Program, California Energy Commission, December 2002.

Rahai, Hamid R. and Hamid Hefazi. Vertical Axis Wind Turbine with Optimized Blade Profile. US Patent No. 7,393,177 B2, filed November 4, 2005, and issued July 1, 2008.

Ruck, B., and P. Lichtneger. Wind Loads on Flat Board and Walls Induced by Passing. Fachtagung "Lasermethodyn in der Strömungsmesstechnik," September 2014. https:/galaev.org/images/Beitraege/Beitraege\%202014/pdf/14.pdf.

Salvadori, Simone, Tommaso Morbiato, Alessandro Mathana, and Enrico Fusto. "On the Characterization of Wind Profile Generated by Road Traffic." In Seventh International Colloquium on Bluff Body Aerodynamics and Applications (BBAA7), 1729-1741. Shanghai, China: September 2-6, 2012.

Soper, David, Christopher Baker, and Mark Sterling. "Experimental Investigation of the Slipstream Development around a Container Freight Train using a Moving Model Facility." Journal of Wind Engineering and Industrial Aerodynamics 135 (2014): 105-117.

U.S. Department of Transportation, Bureau of Transportation Statistics. "U.S. Vehicle-Miles." Accessed September 30, 2020. https://www.bts.gov/content/us-vehicle-miles.

Venning, J., D. L. Jacono, D. Burton, M. Thompson, and J. Sheridan. "The Effect of Aspect Ratio on the Wake of the Ahmed Body." Experiments in Fluids 56 (2015). https://doi.org/10.1007/s00348-015-1996-5. 


\section{About the Authors}

\section{Hamid Rahai, Ph.D.}

Dr. Hamid Rahai is a professor in the Departments of Mechanical and Aerospace Engineering \& Biomedical Engineering and Associate Dean for Research and Graduate Studies in the College of Engineering at CSULB. He has taught various classes at the undergraduate and graduate levels in fluid dynamics, thermodynamics, heat transfer, instrumentation, numerical methods, and turbulence, supervised over 65 M.S. theses and projects and Ph.D. dissertations, and published more than 90 technical papers. He has received over $\$ 8$ million in grants and contracts from the National Science Foundation, Federal Highway Administration, California Energy Commission, California Air Resources Board, Port of Los Angeles, Caltrans, Boeing Company, Southern California Edison, Long Beach Airport, and Long Beach Transit, among others. He was granted a patent for the development of a high-efficiency vertical axis wind turbine (VAWT) and another with Via Verde Company on wind turbine apparatuses. He also has pending patents related to a new diagnostic system for lung diseases using CFD, a new conformal vortex generator tape for reducing wing-tip vortices, and pending patents based on previous MTI-funded research into reducing drag of trailer trucks with rotating cylinders as well as the current study, reducing NOx emissions of gas-powered engines using a humid air system. For the past 26 years, he has been a consultant to local energy and aerospace industries. Dr. Rahai is the recipient of several scholarly and creative activities awards (RSCA), including the 2012 CSULB Impact Accomplishment of the Year in RSCA Award, the 2002-2003 CSULB Distinguished Faculty RSCA Award, and the 2004 Northrop Grumman Excellence in Teaching Award. Dr. Rahai received the Outstanding Engineering Educator Award from the Orange County Engineering Council in California in 2014, and in 2019 he was inducted as a senior member of the National Academy of Inventors (NAI).

\section{Assma Begum, M.S.}

Ms. Assma Begum is a graduate student in the joint Ph.D. program between CSULB College of Engineering and the Claremont Graduate University (CGU) and a research assistant at the Center for Energy and Environmental Research \& Services (CEERS) in the College of Engineering at California State University, Long Beach. She has been involved in various projects at CEERS

related aerodynamics of rotating cylinders and is author and co-author of two technical conference papers. 


\section{Hon. Norman Y. Mineta}

\section{MTI BOARD OF TRUSTEES}

Founder, Honorable Norman

Mineta*

Secretary (ret.),

US Department of Transportation

Chair,

Abbas Mohaddes

President \& COO

Econolite Group Inc.

Vice Chair,

Will Kempton

Executive Director

Sacramento Transportation Authority

Executive Director,

Karen Philbrick, PhD*

Mineta Transportation Institute

San José State University

Winsome Bowen

Chief Regional Transportation

Strategy

Facebook

David Castagnetti

Co-Founder

Mehlman Castagnetti

Rosen \&Thomas

\section{Maria Cino}

Vice President

America \& U.S. Government

Relations Hewlett-Packard

Enterprise

\author{
Grace Crunican** \\ Owner \\ Crunican LLC
}

Donna DeMartino

Managing Director

Los Angeles-San Diego-San Luis

Obispo Rail Corridor Agency

Nuria Fernandez**

General Manager \& CEO

Santa Clara Valley Transportation

Authority (VTA)

\section{John Flaherty}

Senior Fellow

Silicon Valley American

Leadership Form

William Flynn *

President \& CEO

Amtrak

Rose Guilbault

Board Member

Peninsula Corridor

Joint Powers Board

Ian Jefferies*

President \& CEO

Association of American

Railroads
Diane Woodend Jones

Principal \& Chair of Board

Lea + Elliott, Inc.

David S. Kim*

Secretary

California State Transportation

Agency (CALSTA)

Therese McMillan

Executive Director

Metropolitan Transportation

Commission (MTC)

Bradley Mims

President \& CEO

Conference of Minority

Transportation Officials

(COMTO)

Jeff Morales

Managing Principal

InfraStrategies, LLC

Dan Moshavi, PhD*

Dean, Lucas College and Graduate

School of Business

San José State University

Toks Omishakin*

Director

California Department of

Transportation (Caltrans)
Takayoshi Oshima

Chairman \& CEO

Allied Telesis, Inc.

Paul Skoutelas*

President \& CEO

American Public Transportation

Association (APTA)

Beverley Swaim-Staley

President

Union Station Redevelopment

Corporation

Jim Tymon*

Executive Director

American Association of

State Highway and

Transportation Officials

(AASHTO)

Larry Willis*

President

Transportation Trades

Dept.,AFL-CIO

* = Ex-Officio

${ }^{* *}=$ Past Chair, Board of Trustees

\section{Directors}

Karen Philbrick, PhD

Executive Director

Hilary Nixon, PhD

Deputy Executive Director

Asha Weinstein Agrawal, PhD

Education Director

National Transportation Finance

Center Director

\section{Brian Michael Jenkins}

National Transportation Security

Center Director

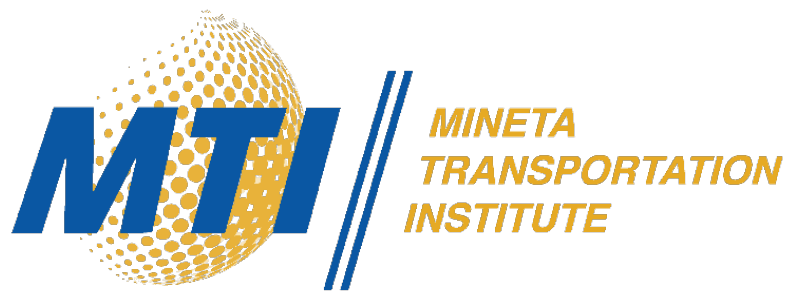

